\title{
Cymothoa indica Schioedte and Meinert, 1884 (Crustacea: Isopoda: Cymothoidae) infestation in cage-cultured Asian seabass Lates calcarifer (Bloch, 1790) from the south-west coast of India
}

\author{
K. SUKUMARAN, M. KAILASAM AND K. P. JITHENDRAN \\ ICAR-Central Institute of Brackishwater Aquaculture, 75, Santhome High Road, Raja Annamalai Puram \\ Chennai, Tamil Nadu - 600 028, India \\ e-mail:krishna@ciba.res.in
}

\begin{abstract}
Infestation of the isopod parasite Cymothoa indica in Asian seabass Lates calcarifer (Bloch, 1790) fingerlings stocked in low volume cages is reported here. Hatchery produced seabass fry, reared to fingerling size (average size, $7 \pm 1 \mathrm{~g}$ and $63 \pm 12$ $\mathrm{mm}$ ) were used for stocking cages in Ashtamudi Lake, Kerala, south-west India. Instances of mortality were first observed on the $25^{\text {th }}$ day of culture (DOC). By the $35^{\text {th }}$ DOC, cumulative mortality of $84.6 \%$ was recorded. Intensity of parasitic infestation was found to be one parasite per fish. Parasites were observed to be latched to the tongue of the host fish. Reddening of buccal cavity, dark pigmentation, tongue degeneration/replacement were observed in the affected fish. On the $35^{\text {th }} \mathrm{DOC}$, surviving fish in the cages were examined and the prevalence of $C$. indica was $53.08 \%$ in the remaining live fish. Though experimental infestation of Asian seabass by $C$. indica has been reported previously under laboratory conditions, this forms the first report on infestation of $C$. indica in cage-cultured Asian seabass.
\end{abstract}

Keywords: Asian seabass, Cage culture, Cymothoa indica, Isopoda, Lates calcarifer

The Asian seabass Lates calcarifer (Bloch, 1790) is one of the alternative species for promoting diversity in farmed brackishwater species. In India, cage culture in brackishwater is a relatively recent practice and its adoption has seen a gradual increase in the past decade through low volume cage culture of $L$. calcarifer (Vijayan et al., 2015) and pearlspot, Etroplus suratensis (Pramod Kiran et al., 2014). Pro-active initiatives for addressing the issues related to fish health is important for sustainable aquaculture development (Bondad-Reantaso et al., 2005).

Cymothoid isopods comprise about 40 genera and over 380 accepted species (Smit et al., 2014). Among these, 45 species infesting fishes have been reported from India (Rameshkumar et al., 2016; Aneesh et al., 2017). Cymothoa indica infestation in Asian seabass larvae was first reported under laboratory conditions by Rajkumar et al. (2005b). Cymothoid infestation was also reported in the long whiskered catfish Mystus gulio cultured in cages at Vellar Estuary in the south-east coast of India (Rajkumar et al., 2005a). The present report is of $C$. indica parasitising and causing significant mortality in Asian seabass cultured in low volume cages in the south-west coast of India.

Fish were cultured in five cages off Kochuthuruthu Island, Chavara, Kollam in Ashtamudi Lake (8'57'28.4'N;
76'32'38.7'E), Kerala, India. Double-walled, low volume HDPE net cages $(1.5 \times 1.5 \times 1 \mathrm{~m})$ of mesh size $12 \mathrm{~mm}$ were fixed in shallow area adjoining Kochuthuruthu Island in Ashtamudi Lake. L. calcarifer fry stocked were produced at finfish hatchery, Muttukadu experimental station of ICAR-Central Institute of Brackishwater Aquaculture (ICAR-CIBA), Chennai and reared to fingerling size in net cages at Pulicat Lake, Tamil Nadu. Fingerlings of average initial size $7 \pm 1 \mathrm{~g}$ and $63 \pm 12 \mathrm{~mm}$ (total length, TL) were stocked at 200 individuals per cage at a stocking density of 89 nos. $\mathrm{m}^{-3}$. Fishes were initially fed on pellet feed and gradually weaned (within 3-4 days) to feed on trash fish, sardines and anchovies at $20 \%$ of the average fish body weight per day (twice daily). Size grading was done 10 days after stocking as a management measure to minimise cannibalism.

The water quality parameters were regularly monitored during the culture period. Temperature and $\mathrm{pH}$ were measured using a digital meter (Lab India, India), salinity was measured using refractometer (Atago, India). Ammonia-N and nitrite- $\mathrm{N}$ were analysed following standard methods (APHA, 1995). All the fish were routinely sampled for assessing growth, health status and presence of parasites. Various parameters of growth as well as mortality were calculated using the following formulae: 


$$
\begin{aligned}
& \text { Weight gain (\%) } \\
& =(\text { Final weight }- \text { Initial } \\
& \text { weight) }{ }^{*} 100 / \text { Initial weight. } \\
& \text { Specific growth rate } \\
& \left(\% \text { day }^{-1}\right) \\
& =\ln \text { (Final weight of fish) }-\ln \\
& \text { (Initial weight of fish) x 100/ } \\
& \text { Days of culture. } \\
& =(\text { No. of fish stocked }- \text { No. of fish } \\
& \text { survived) x 100/No. of fish } \\
& \text { stocked }
\end{aligned}
$$

Instances of mortality were first observed on the $25^{\text {th }}$ day of culture (DOC) and on the $35^{\text {th }}$ DOC severe mortality due to infestation by cymothoid parasite was recorded. Surviving fish were examined for the presence of external parasites or lesions. Body surface, gill filaments and buccal cavity were also examined for the presence of parasitic infestation. The weight $(\mathrm{g})$ and total length $(\mathrm{mm})$ of the fish were recorded. Live cymothoids were fixed in $5 \%$ formaldehyde and identified using taxonomical keys of Trilles and Bariche (2006) and Martin, et al. (2016). The prevalence $(\mathrm{P})$ and intensity $(\mathrm{I})$ of the recovered isopods were calculated as per the methods described in Margolis et al., (1982) and Bush et al. (1997).

Mortality was first observed in seabass fingerlings in all the five cages (Table 1) after 25-28 days of culture (DOC). During the initial three days, mortality (\%) ranged between $2-5 \%$. By the $35^{\text {th }} \mathrm{DOC}$, a cumulative mortality of $84.6 \%$ was recorded and a total of 81 out of 154 surviving fish were found to be infested with isopod parasites. The isopods collected were identified as Cymothoa indica Schioedte and Meinert, 1884. This species has been widely reported from south-eastern Pacific and Indian Ocean, from Bangkok (Schioedte and Meinert, 1884); Beirut (Trilles and Bariche, 2006); India (Chilton, 1924; Veerapan and Ravichandran, 2000; Rajkumar et al., 2004, 2005a, b; Trilles and Bariche, 2006; Ravi and Rajkumar, 2007; Trilles et al,. 2011; Aneesh, 2014); Australia (Hale, 1926; McNeill, 1926; Jones et al., 2008; Martin et al., 2016); Indonesia (Nierstrasz, 1931; Trilles, 2008) and Vietnam (Trilles, 1975). C. indica, has been reported from a wide range of fish species belonging to the family Carangidae, Cynoglossidae, Sillaginidae and from an unknown eel (Martin et al., 2016). The parasite has also been reported to infect long whiskers catfish, Mystus gulio; spot tail needlefish Strongylura strongylura (Rajkumar et al., 2004), Bloch's gizzard shad Nematalosa nasus; maned gobi Oxyurichthys microlepis (Ravi and Rajkumar, 2007), goby Glossogobius giuris (Chilton, 1924), larvae of barramundi Lates calcarifer (Rajkumar et al., 2005a), streaked spinefoot Siganus javus (Rajkumar et al., 2005b), common pandora Pagellus erythrinus (Trilles and Bariche, 2006), yellowstripe barracuda Sphyraena chrysotaenia (Trilles and Bariche, 2006), obtuse barracuda Sphyraena obtusata (Veerapan and Ravichandran, 2000; Trilles and Bariche, 2006), snakefish Synodus myops (Veerapan and Ravichandran, 2000; Trilles and Bariche, 2006), Oreochromis mossambicus (Rameshkumar and Ravichandran, 2010) and Etroplus suratensis (Aneesh, 2014).

The intensity of parasitic infestation was found to be 1 parasite per fish. Parasites were observed to be latched to the tongue of the host fish (Fig. 1). Most of the affected fish were observed to be emaciated with dark pigmentation. Reddening of buccal cavity, degeneration and loss of tongue were also observed in a few of the infested fish.

The water quality parameters recorded during the initial period of culture were: salinity - $25 \%$, temperature $-31^{\circ} \mathrm{C}, \mathrm{pH}-6.3$, ammonia-N - $0.03 \mathrm{mg} \mathrm{l}^{-1}$ and nitrite-N $0.08 \mathrm{mg}^{-1}$. On the $35^{\text {th }} \mathrm{DOC}$, the water quality parameters recorded were: salinity $-21 \%$, temperature $-30^{\circ} \mathrm{C}, \mathrm{pH}$ 6.25 , ammonia-N - $0.02 \mathrm{mg} \mathrm{l}^{-1}$ and nitrite- $\mathrm{N}-0.07 \mathrm{mg} \mathrm{l}^{-1}$. After 35 days, the fingerling had grown from an average size of $7 \pm 1 \mathrm{~g}$ and $63 \pm 12 \mathrm{~mm}$ (total length, TL) to $3.78 \pm 0.3$ - 38.03 $\pm 0.47 \mathrm{~g}$ and $75.87 \pm 3.21-116.96 \pm 1.95 \mathrm{~mm}(\mathrm{TL})$ in different cages. A condition factor below 1; of $0.88 \pm 0.02$ and $0.87 \pm 0.05$ were observed in cages 4 and 5 , where the incidence of parasites was relatively more $(72-75 \%)$ in the surviving fish population (Table 1).

Previously Cymothoa sp. and Aegothoa sp. were reported from aquaculture systems in Thailand (Leong and Wong, 1990). A study of parasitic fauna of L. calcarifer under mariculture in Indonesia recorded nineteen parasite

Table 1. Total length $(\mathrm{mm})$, body weight $(\mathrm{g})$, condition factor, mortality $(\%)$ and prevalence $(\%)$ of isopod $(C$. indica) infestation in Asian seabass stocked in five cages on $35^{\text {th }}$ day of culture. Values are Mean $\pm \mathrm{SE}$

\begin{tabular}{llllll}
\hline Cage & Weight $(\mathrm{g})$ & Total length $(\mathrm{mm})$ & Mortality $(\%)$ & Prevalence $(\%)$ & Condition factor \\
\hline 1 & $38.03 \pm 0.47$ & $116.96 \pm 1.95$ & 86 & 31.82 & $2.45 \pm 0.09$ \\
2 & $23.16 \pm 0.40$ & $94.40 \pm 1.51$ & 81 & 57.90 & $2.86 \pm 0.12$ \\
3 & $11.91 \pm 0.54$ & $82.95 \pm 1.35$ & 89.5 & 28.57 & $2.10 \pm 0.09$ \\
4 & $5.00 \pm 0.59$ & $82.80 \pm 0.58$ & 70.5 & 72.13 & $0.88 \pm 0.02$ \\
5 & $3.78 \pm 0.30$ & $75.87 \pm 3.21$ & 96 & 75.00 & $0.87 \pm 0.05$ \\
\hline
\end{tabular}




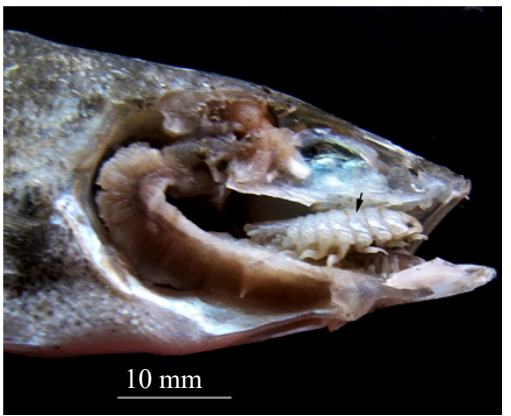

(a)

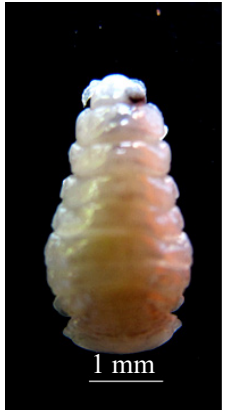

(b)

Fig. 1. (a) C. indica ovigerous female in the buccal cavity of of Asian seabass fingerling, (b) Dorsal view of $C$. indica

species, but no isopod parasites were observed (Ruckert et al., 2008). Mortality of cage-cultured L. calcarifer in south-west coast of India due to parasitic infestation of the isopod Cirolana fluviatilis has been reported by Sanil et al. (2009). Infestation of L. calcarifer larvae (28 day old) by $C$. indica under laboratory conditions was reported by Rajkumar et al. (2005a). However, occurrence of C. indica in L. calcarifer from either wild or aquaculture systems has not been reported so far. In L. calcarifer, parasitic isopods; Nercila barramundae from Australia (Bruce, 1987) and Rocinela latis from Calcutta, India (Southwell, 1915) were listed by Hutson (2013) while reviewing the pathogens affecting captive and wild Asian seabass.

Previous reports of parasitic isopod infestations inflicting mortalities in fish reared in aquaculture systems in India include, C. indica infestations in Mystus gulio from Vellar Estuary which led to $100 \%$ mortality within 10 days (Rajkumar et al., 2005b) and infestations with the isopod, C. fluviatilis infesting L. calcarifer in Cochin backwaters leading to cumulative mortality of $45 \%$ in six months (Sanil et al., 2009). The productivity and economic viability of any finfish aquaculture enterprise can be severely compromised by outbreaks of parasitic diseases (Shinn et al., 2015). Globally, development of cage culture has witnessed the emergence of various parasitic diseases owing to higher host population density (Kent, 2000; Murray and Peeler, 2005). Often, the dominant parasite species infecting fish in captivity may be rare or absent in their wild counterparts or even when present, their deleterious effects may be relatively less evident (Horton and Okamura, 2001; Nowak, 2007). Experimental infestation of seabass larvae by $C$. indica showed the site of infestation as branchial and antero-dorsal region of the fish (Rajkumar et al., 2005a). In the present study, C. indica were latched to the tongue of seabass fingerlings. The intensity of parasitic infestation observed during the present investigation (1 parasite per fish) was similar to

that observed in seabass juveniles and blue spot mullet (1-2 parasite per individual) by Leong and Wong (1990) and Al-Zubaidy and Mahaisen (2014) respectively. In $M$. gulio, 1-3 numbers of $C$. indica were found to be lodged on the floor of buccal cavity, clinging firmly to tongue of the host (Rajkumar et al., 2005b).

Experimental infestation of seabass larvae with C. indica led to haemorrhagic skin lesions and eroded scales with abundant mucus (Rajkumar et al., 2005a). Gross lesions in the buccal cavity and callus like thickening on the gill arch and filaments were observed in $O$. microlepis infested with $C$. indica (Ravi and Rajkumar, 2007). In the present study, majority of the affected seabass fingerlings were found to be emaciated with dark pigmentation. Reddening of buccal cavity, degeneration and loss of tongue were also observed in infected fish.

Condition factor, an index of fish health has been used to indicate the effect of parasites on their hosts (Horton and Okamura, 2001). Initially, the fish were graded based on size and distributed into different cages based on size to minimise cannibalism. The condition factor for the five different cages ranged from $0.87 \pm 0.05$ to $2.86 \pm 0.12$. The smallest fishes stocked separately in two cages (cage 4 and 5) had the lowest condition factor of $0.88 \pm 0.02$ and $0.87 \pm 0.05$ respectively and had the highest prevalence of parasites i.e., 72.13 and $75.0 \%$ respectively, indicating correlation between prevalence and poor condition of the fish. Growth rates, energy reserves and longevity were reported to be severely compromised due to cymothoid infestation in five-lined cardinal fish Cheiolodipterus quinquelineatus (Fogelman et al., 2009). Relatively lower body weight in males, up to $20 \%$ and females, up to $32 \%$ were recorded in gobiid fish due to C. indica infestation (Ravi and Rajkumar, 2007). Barber et al. (2000) and Rameshkumar et al. (2013) also reported intra-buccal obstruction causing reduced food intake in L. calcarifer infested with cymothoan parasites and disturbed respiration (Parker and Booth, 2013). In the present study, relatively lower condition factor was observed in seabass fingerlings with higher prevalence of C. indica.

In an open water cage system, an effective anti-parasitic treatment may be both challenging and expensive (Nowak, 2007). No other specific control measures other than optimum culture practices have been suggested for limiting the parasite (Jithendran et al., 2008). Use of fine mesh nets around the cages has been suggested as a preventive measure against transmission of cymothoan larvae (Bragoni et al., 1984). In India, cage culture of finfishes is currently in its nascent stages. Devising efficient management strategies to optimise the 
health of fish and preventing disease outbreaks will help expansion of sustainable cage fish farming in India.

\section{Acknowledgements}

The authors are grateful to Dr. K. K. Vijayan, Director, ICAR-CIBA, Chennai for encouragement and for providing all the necessary facilities for this study. We thank Dr. K. Sudha, Associate Professor, Sree Narayana College, Kannur; Dr. R. B. Pramod Kiran, Asst. Professor and Dr. P. T. Aneesh, Post-doctoral Student Dept. of Aquatic Biology and Fisheries, University of Kerala for sharing their expertise on $C$. indica and their invaluable support during data collection and recording; Dr. N. K. Sanil, Scientist, ICAR-CMFRI, Kochi, Dr. C. P. Balasubramanian, Principal Scientist, ICARCIBA, Dr. Vidya Rajendran, Scientist, Dr. J. Balamurugan, Post- doctoral Student, ICAR-CIBA for their critical evaluation and suggestions for improvement of the manuscript.

\section{References}

Al-Zubaidy, A. B. and Mhaisen, F. T. 2014. The blue spot mullet Moolgarda seheli (Forsskal, 1775) a new host for the crustacean parasite Cymothoa indica. Am. J. Biol. Life Sci., 2: $58-62$.

Aneesh, P. T. 2014. Studies on parasitic crustaceans infesting the fishes of Malabar coast. Ph. D. dissertation, Kannur University, India, $147 \mathrm{pp}$.

Aneesh, P. T., Valarmathi, K. and Santanu, M. 2017. Re-description of Nerocila recurvispina Schioedte and Meinert, 1881: (Crustacea: Isopoda) from Hooghly River Kolkata, India. Mar. Biodivers., 1-13.

APHA 1995. Standard methods for the examination of water and wastewater. American Public Health Association/ American Water Works Association/Water Environment Federation, Washington DC, USA.

Barber, I., Hoare, D. and Krause, J. 2000. Effects of parasites on fish behaviour: a review and evolutionary perspective. Rev. Fish Biol. Fish., 10: 131-65. DOI: 10.1023/A:1016658 224470 .

Bondad-Reantaso, M. G., Subasinghe, R. P., Arthur, J. R., Ogawa, K., Chinabut, S., Adlard, R., Tan, Z. and Shariff, M. 2005. Disease and health management in Asian aquaculture. Vet. Parasitol., 132 : 249-72. DOI: 10.1016/j. vetpar.2005.07.005.

Bragoni, G., Romestand, B. and Trilles J. P. 1984. Parasitoses a Cymothoadien Chez Le Loup, Dicentrarchus Labrax (Linnaeus, 1758) En Élevage I. Ecologie Parasitaire Dans Le Cas De L'Etang De Diana (Haute-Corse) (Isopoda, Cymothoidae). Crustaceana, 47(1): 44-51.
Bruce, N. L. 1987. Australian species of Nerocila Leach, 1818 and Creniola n. gen. (Isopoda: Cymothoidae), crustacean parasites of marine fishes. Rec. Aust. Mus., 39: 355-412.

Bush, A. O., Lafferty, K. D., Lotz, J. M. and Shostak, A. W. 1997. Parasitology meets ecology on its own terms: Margolis et al. revisited. J. Parasitol., 575-583.

Chilton, C. 1924. Fauna of the Chilka Lake. Tanaidacea and Isopoda. Mem. Indian Mus., 5: 875-895.

Fogelman, R. M., Kuris, A. M. and Grutter, A. S. 2009. Parasitic castration of a vertebrate: effect of the cymothoid isopod, Anilocra apogonae, on the five-lined cardinal fish, Cheilodipterus quinquelineatus. Int. J. Parasitol., (39): 577-583. DOI: 10.1016/j.ijpara.2008.10.013.

Hale, H. M. 1926. Review of Australian isopods of the cymothoid group. Part II. T. Roy. Soc. South Aust., 50: 201-234.

Horton, T. and Okamura, B. 2001. Cymothoid isopod parasites in aquaculture: a review and case study of a Turkish seabass (Dicentrarchus labrax) and seabream (Sparus auratus) farm. Dis. Aquat. Org., 46: 181-188. DOI: 10.3354/ dao046181.

Hutson, K. S. 2013. Infectious diseases of Asian seabass and health management. In: Gerry D. R. (Ed.) Biology and culture of Asian seabass Lates calcarifer. CRC Press, Taylor and Francis, USA, p. 102-136.

Jithendran, K. P., Natarajan, M. and Azad, I. S. 2008. Crustacean parasites and their management in brackishwater finfish culture. Aquac. Asia, 13: 47-50.

Jones, C. M., Miller, T. L., Grutter, A. S. and Cribb, T. H. 2008. Natatory-stage cymothoid isopods: description, molecular identification and evolution of attachment. Int. J. Parasitol., 38: 477-491.

Kent, M. L. 2000. Marine net pen farming leads to infections with some unusual parasites. Int. J. Parasitol., 30: 321-326.

Leong, T. S. and Wong, S. Y. 1990. Parasites of healthy and diseased juvenile grouper Epinephelus malabaricus (Bloch and Schneider) and seabass Lates calcarifer (Bloch) in floating cages in Penang, Malaysia. Asian Fish. Sci., 3: 319-327.

Margolis, L., Esch, G. W., Holmes, J. C., Kuris, A. M. and Schad, G. 1982. The use of ecological terms in parasitology (Report of an Ad hoc Committee of the American Society of Parasitologists). J. Parasitol., 68(1): 131-133.

Martin, M. B., Bruce, N. L. and Nowak, B. F. 2016. Review of the fish-parasitic genus Cymothoa Fabricius, 1793 (Crustacea: Isopoda: Cymothoidae) from Australia. Zootaxa, 4119(1): $1-72$

McNeill, F. A. 1926. The biology of North-West Islet, Capricorn Group. Aust. Zool., 4: 297-318. 
Murray, A. G. and Peeler, E. J. 2005. A framework for understanding the potential for emerging diseases in aquaculture. Prev. Vet. Med., 67: 223-235.

Nash, R. D. M., Valencia, A. H. and Geffen, A. J. 2006. The origin of Fulton's condition factor-setting the record straight. Fisheries, 31: 236-238.

Nierstrasz, H. E. 1931. Isopoda genuina. II. Flabellifera. In: Weber, M. and De Beaufort, L.F. (Eds.), The isopods of the Siboga Expedition. Siboga Expedition (Outcomes in Zoological, Botanical, Oceanographic and Geological Area collected in the East Indies, 1899-1900 on board H.M. Siboga under command of Lieutenant Commander 1st class G.F. Tydema), E. J. Brill, Leiden, p. 123-233. (In Dutch).

Nowak, B. F. 2007. Parasitic diseases in marine cage culture An example of experimental evolution of parasites? Int. J. Parasitol., 37: 581-588. DOI: 10.1016/j.ijpara.2007.01.003.

Parker, D. and Booth, A. J. 2013. The tongue-replacing isopod Cymothoa borbonica reduces the growth of large spot pompano Trachinotus botla. Mar. Biol., 160: 2943-2950.

Pramod Kiran, R. B., Baiju, A., Sukumaran, K., David, N. S., Bijukumar, A. and Arasu, A. R. T., 2014. Cage culture of native cichlid, Etroplus suratensis (pearlspot) in Kerala, India: A laudable initiative towards emergence of small scale cage culture. Aquac. Asia, 11: 16-18.

Rajkumar, M., Perumal, P. and Trilles, J. P. 2005a. Cymothoa indica (Crustacea, Isopoda, Cymothoidae) parasitises the cultured larvae of the Asian seabass Lates calcarifer under laboratory conditions. Dis. Aquat. Org., 66: 87-90. DOI: $10.3354 /$ dao065269.

Rajkumar, M., Perumal, P. and Trilles, J. P. 2005b. First record of Cymothoa indica (Crustacea, Isopoda, Cymothoidae) infecting the cultured catfish Mystus gulio in India. Dis. Aquat. Org., 65: 269-272. DOI: 10.3354/dao066087.

Rajkumar, M., Santhanam, P. and Perumal, P. 2004. Report on new host record of Cymothoa indica (Schioedte \& Meinert, 1884) (Crustacea: Isopoda) from Parangipettai coastal waters, south-east coast of India. J. Aquat. Biol., 19: 113-114.

Rameshkumar, G. and Ravichandran, S. 2010. Cymothoa indica (Isopoda; Cymothoidae) and Alitropus typus (Isopoda; Aegidae) on freshwater fish Tilapia mossambica (Cichlidae) in Vellar Estuary, south-east coast of India. Revista Biotemas, 23: 67-70.

Rameshkumar, G., Ravichandran, S., Sivasubramanian, K. and Trilles, J. P. 2013. New occurrence of parasitic isopods from Indian fishes. J. Parasit. Dis., 37: 42-46. doi: 10.10 07/s12639-012-0128-x.

Rameshkumar, G., Ramesh, M., Ravichandran, S. and Trilles, J. P. 2016. Parasitic isopods from marine fishes off Nagapattinam coast, India. J. Parasit. Dis., 40(3): 940-944.
Ravi, V. and Rajkumar, M. 2007. Effect of isopod parasite, Cymothoa indica on gobiid fish, Oxyurichthys microlepis from Parangipettai coastal waters (South-east coast of India). J. Environ. Biol., 28: 251-256.

Ruckert, S., Palm, H. W. and Klimpel, S. 2008. Parasite fauna of seabass (Lates calcarifer) under mariculture conditions in Lampung Bay, Indonesia. J. Appl. Ichthyol., 24(3): 321-327.

Sanil, N. K., Vikas, P. A., Ratheesh, T. B., George, K. C. and Vijayan, K. K. 2009. Mortalities caused by the crustacean isopod, Cirolana fluviatilis, in tropical, cage-cultured Asian seabass, Lates calcarifer: a case study from the south-west coast of India. Aquac. Res., 40: 1626-1633. doi. org/10.1111/j.1365-2109.2009.02263.x.

Schioedte, J. C. and Meinert, F. 1884. Symbolae ad monographium Cymothoarum crustaceorum isopodum familiæ. IV. Cymothoidæ Trib. II. Cymothoinæ. Trib. III: Lironecinæ. Naturhistorisk Tidsskrift, Kjøbenhavn, 14: 221-454.

Shinn, A. P., Pratoomyot, J., Bron, J. E., Paladini, G., Brooker, E. E. and Brooker, A. J. 2015. Economic costs of protistan and metazoan parasites to global mariculture. Parasitol., 142: 196-270. doi: 10.1017/S0031182014001437.

Smit, N. J., Bruce, N. L. and Hadfield, K. A. 2014. Global diversity of fish parasitic isopod crustaceans of the family Cymothoidae. Int. J. Parasitol. Parasit. Wild., 3: 188-197. doi: 10.1016/j.ijppaw.2014.03.004.

Southwell, T. 1915. Notes from the Bengal Fisheries Laboratory, Indian Museum. No. 2. On some Indian parasites of fish, with a note on carcinoma in trout. Rec. Indian Mus., 11: 311-330.

Trilles, J. P. 1975. Cymothoidae (Isopoda, Flabellifera) from collections of the National Museum of Natural History in Paris. III. The Cymothoinae Schioedte and Meinert, 1884 Genus Cymothoa Fabricius, 1787. Bulletin of the National Museum of Natural History, Paris, 4th Sseries, Zoology, 318: 977-993 (In French).

Trilles, J. P. 2008. Some marine isopods from the Senckenberg Research Institute (Frankfurt am Main, Germany) (Crustacea, Isopoda: Cymothoidae, Aegidae, Corallanidae, Cirolanidae). Senckenbergiana Biologica, 88: 21-28.

Trilles, J. P. and Bariche, M. 2006. First record of the Indo-Pacific Cymothoa indica (Crustacea, Isopoda, Cymothoidae), a Lessepsian species in the Mediterranean Sea. Acta Parasitol., 51(3): 223-230.

Trilles, J. P., Ravichandran, S. and Rameshkumar, G. 2011 A checklist of the Cymothoidae (Crustacea, Isopoda) recorded from Indian fishes. Acta Parasitol., 56: 446-459. DOI: $10.2478 / \mathrm{s} 11686-011-0077-z$. 
Veerapan, N. and Ravichandran, S. 2000. Isopod parasites from marine fishes of Parangipettai coast. UGC-SAP Monograph series, Annamalai Univerisity, Parangipettai, India, $24 \mathrm{pp}$.
Vijayan, K. K., Rajendran, K. V., Sanil, N. K. and Alavandi, S. V. 2015. Fish health management in cage aquaculture. In: Ignatius, B. and Joseph, I. (Eds.), Souvenir, $5^{\text {th }}$ International symposium on cage aquaculture in Asia. Asian Fisheries Society and ICAR-Central Marine Fisheries Research Institute, Kochi. p. 94-103. 